\title{
Comparison of the Efficacy of Cefazolin with and without Naproxen in Patients with Cellulitis Admitted to a Tertiary Hospital: 2019-2020
}

\author{
2019-2020 Yılları Arasında Üçüncü Basamak Bir Hastaneye Yatııılan Selülitli Hastalarda \\ Naproksenli ve Naproksensiz Sefazolinin Etkinliğinin Karşılaştııılması
}

\author{
(D) Shabnam TEHRANI, (D) Behnood HATAMI, (D) Sadaf SAKET, D Amirreza KEYVANFAR \\ Shahid Beheshti University of Medical Sciences, Infectious Diseases and Tropical Medicine Research Center, Tehran, Iran
}

\section{Abstract}

Introduction: It is pertinent to carefully monitor the clinical course of patients with cellulitis. If not treated properly, there is a possibility of its extension to other skin surfaces, recurrent infection, risk of systemic spreading, and incidence of worse complications, such as sepsis and severe abscesses. Various antibiotic regimens with or without anti-inflammatory drugs have been administered as a treatment against cellulitis. However, there is no proposed standard and selective line of treatment against cellulitis. This study aimed to compare the efficacy and outcome of two medications, cefazolin alone and cefazolin combined with naproxen as a non-steroidal anti-inflammatory drug.

Materials and Methods: This open-label randomized clinical trial was conducted on patients with cellulitis who were admitted to Labbafinejad Hospital (Tehran, Iran) from May 2019 to March 2020. The patients were randomly divided into group A (treated with 1-1.5 g of cefazolin alone intravenously every eight hours) and group B (treated with 1-1.5 g of cefazolin intravenously every eight hours combined with 500 mg of naproxen orally every 12 hours). The responses to these medications and the side effects were evaluated during hospitalizations.

Results: The mean age of the 64 patients included in the study was $50.52 \pm 2.10$ years and $51.56 \%$ of the patients were male. There were no significant differences between the control $(n=33)$ and intervention $(n=31)$ groups in terms of history of diabetes mellitus ( $p=0.666)$, antibiotic use $(p=0.594)$, trauma $(p=0.722)$, cellulitis $(p=0.529)$, and smoking $(p=0.705)$. The mean body temperatures of the two groups were not different in any of the first $(p=0.762)$, third ( $p=0.789)$, and fifth ( $p=0.893)$ days. The improvement of clinical symptoms on the third day was significantly ( $p=0.045)$ more in group B (90.3\%) than in group A (51.5\%). Also, the clinical improvement on the fifth day was significantly ( $p=0.036)$ higher in group B $(100 \%)$ than in group $A(69.7 \%)$. In addition, the mean hospitalization periods in the control $(5.62 \pm 1.00)$ and intervention $(4.04 \pm 1.00)$ groups were significantly different $(p=0.012)$.

Conclusion: In patients diagnosed with cellulitis, the combination therapy with cefazolin and naproxen was far more effective than the monotherapy with cefazolin. Administration of the first regimen improves clinical manifestations and shortens hospitalization.

Keywords: Cellulitis, treatment outcome, cefazolin, naproxen 
Giriş: Selülitli hastaların klinik seyrini dikkatle izlemek gereklidir. Çünkü uygun şekilde tedavi edilmezse; diğer deri yüzeylerine yayılma, tekrarlayan enfeksiyon ve sistemik yayılma söz konusu olabilir ya da sepsis ve şiddetli apse gibi daha kötü komplikasyonların görülme riski vardır. Selülit tedavisi için anti-enflamatuvar ilaçlar içeren veya içermeyen çeşitli antibiyotik rejimleri uygulanmıştır. Ancak selülit için önerilen standart ve seçici bir tedavi bulunmamaktadır. Bu çalışmanın amacı, tek başına sefazolin ile non-steroid antienflamatuvar bir ilaç olan naproksen ve sefazolin kombinasyonunun etkinliğini ve sonuçlarını karşılaştırmaktır.

Gereç ve Yöntem: Bu açık etiketli randomize klinik çalışma, Mayıs 2019 ile Mart 2020 arasında Labbafinejad Hastanesi'ne (Tahran, İran) başvuran selülitli hastalar üzerinde gerçekleştirildi. Hastalar rastgele; tek başına sefazolin (sekiz saatte bir intravenöz 1-1,5 g) ile tedavi edilen grup A'ya ve sefazolin (sekiz saatte bir intravenöz 1-1,5 g) ile kombine naproksen (12 saatte bir oral $500 \mathrm{mg}$ ) ile tedavi edilen grup B'ye dahil edildi. Daha sonra yatışlar sırasında ilaçlara yanıt ve yan etkiler değerlendirildi.

Bulgular: Çalışmaya alınan 64 hastanın yaş ortalaması 50,52 $\pm 2,10$ yıl olup hastaların \%51,56'sı erkekti. Kontrol ( $n=33$ ) ve müdahale ( $n=31)$ grupları arasında diyabetes mellitus $(p=0,666)$, antibiyotik kullanımı $(p=0,594)$, travma $(p=0,722)$, selülit $(p=0,529)$ ve sigara $(p=0,705)$ öyküleri açııından fark yoktu. İki grubun ortalama vücut sıcaklıkları birinci $(p=0,762)$, üçüncü $(p=0,789)$ ve beşinci $(p=0,893)$ günlerin hiçbirinde farklı değildi. Üçüncü günde klinik semptomlardaki iyileşme, grup B'de $(\% 90,3)$ grup A'ya $(\% 51,5)$ göre daha fazlaydı ve fark istatistiksel olarak anlamlıydı $(p=0,045)$. Ayrıca, beşinci gündeki klinik iyileşme, grup B'de (\%100), grup A'ya $(\% 69,7)$ göre daha yüksekti ve fark istatistiksel olarak anlamlıydı $(p=0,036)$. Ayrıca kontrol ve müdahale gruplarında ortalama yatış süreleri sırasıyla $5,62 \pm 1,00$ ve $4,04 \pm 1,00$ idi $(p=0,012)$.

Sonuç: Selülit teşhisi konan hastalarda sefazolin ve naproksen ile kombinasyon tedavisi, sefazolin ile monoterapiden çok daha etkiliydi. Sefazolin ve naproksen rejimin uygulanması klinik belirtileri iyileştirir ve hastanede kalış süresini kısaltır.

Anahtar Kelimeler: Selülit, tedavi sonucu, sefazolin, naproksen

\section{Introduction}

Cellulitis results from the penetration of predominant bacterial infections from damaged skin barriers. It is a common condition with an annual incidence of about 2,500 per 100,000 cases in 2006 in the US. Lower limb involvement was reported in $70-80 \%$ of cases and is equal in men and women. Cellulitis is common in middle-aged and older adults ${ }^{[1,2]}$. Cellulitis mainly manifests as local warmth, edema, and erythema. The plaque in the affected area has an irregular margin and may invade healthy skin surfaces, creating an unexpected pattern ${ }^{[3]}$. The predisposing factors are classified into local and systemic. Among the local factors, interdigital intertrigo has taken the first place. Bacteria can accumulate in interdigital spaces where the colonization by Streptococcus or Staphylococcus aureus is common ${ }^{[4,5]}$. Impaired skin barrier due to wounds, trauma, edema, radiotherapy, or dermatosis is another risk factor ${ }^{[6]}$. Venous insufficiency caused by stasis dermatitis, venous ulcers, lymphedema, or lymphatic diseases constitutes another risk factor $^{[7]}$. Another risk factor is the previous history of cellulitis, which has a recurrent rate of $8-20 \%$ over a period of 1-3 years ${ }^{[8]}$. Furthermore, smoking, diabetes mellitus, alcoholism, immunosuppression, and a history of cancer are all risk factors for cellulitis. Moreover, genetic susceptibility to cellulitis has been reported ${ }^{[9,10]}$.

Evidence of recent streptococcal infection has also been reported in approximately $82 \%$ of patients with lower limb cellulitis, which has a diagnostic value ${ }^{[9]}$.

In general, staphylococci and streptococci predominantly cause cellulitis. Thus, the first-line treatment includes firstgeneration cephalosporins or cloxacillin. If the clinical response is appropriate, clinical improvement will be seen within 2448 hours. Oral antibiotics are sufficient for mild cellulitis. Using intravenous antibiotics, despite the oral treatment, is recommended in cases with systemic toxicity, immune deficiency, rapid and widespread progression of cellulitis, presence of progressive erythema, or exacerbation of symptoms within 4872 hours. The duration of treatment also varies by individual. A 5-7 days course of treatment is sufficient for patients with uncomplicated cellulitis; however, continued treatment for up to 10-14 days will be necessary for severe episodes ${ }^{[11]}$. Clindamycin is recommended for patients with penicillin allergies. However, it should be noted that the treatment protocol is based on whether or not cellulitis is purulent ${ }^{[12]}$. In purulent cases and with evidence of abscess, treatment should be accompanied by coverage against methicillin-resistance Staphylococcus aureus (MRSA) strains. Monotherapy with cotrimoxazole or clindamycin is recommended in outpatient treatment; however, clindamycin, vancomycin, or linezolid in inpatient settings can be used in the treatment of cellulitis ${ }^{[11]}$. Non-steroidal anti-inflammatory drugs (NSAIDs) can potentially reduce inflammation, accelerate the healing process, and treat cellulitis along with antibiotics ${ }^{[13]}$. Due to the risks and effects of cellulitis, it is pertinent to treat patients with novel and effective drugs ${ }^{[14]}$. Previous studies have suggested that NSAIDs are more effective in treating cellulitis than antibiotics ${ }^{[15,16]}$. In addition, a study determining the effect of cephalexin and NSAIDs combination therapy compared with monotherapy in the treatment of cellulitis has shown that the combination therapy accelerates the recovery process and eliminates local inflammation ${ }^{[17]}$. Therefore, we decided to evaluate the efficacy of naproxen in combination with first-line antibiotic therapy in the treatment of cellulitis. 


\section{Materials and Methods}

This randomized clinical trial was an open-label study without blinding. The study was conducted with patients with cellulitis who were admitted to Labbafinejad hospital (Tehran, Iran). Patients were recruited from May 2019 to March 2020. The inclusion criteria were hospitalization with a diagnosis of cellulitis, patients' age of over 18 years, and patients' willingness to participate in the clinical trial. On the other hand, the exclusion criteria of the study were allergy to penicillin, cefazolin or naproxen, immunodeficiency, mucocutaneous diseases, kidney diseases, venous catheter, history of infected diabetic foot ulcer, bite or presence of a foreign body the wound, perianal cellulitis, recent hospitalization history, chronic hemodialysis, pregnant women, injection drug abusers, suspected septic arthritis, or osteomyelitis.

\section{Study Procedure}

Eligible patients were divided into control (A) and intervention (B) groups with the aid of a random number table. First, the baseline characteristics (medical history, signs, and symptoms) were evaluated. Group A was treated with cefazolin alone (intravenous 1-1.5 g every eight hours) and group B was treated with cefazolin (intravenous 1-1.5 g every eight hours) in combination with naproxen (oral $500 \mathrm{mg}$ every 12 hours).

\section{Outcomes Assessment}

On the third, fifth, and seventh day of treatment, a trained physician evaluated the patients' clinical improvement.

Signs of clinical improvement included cessation of fever and reduction in the extent of cellulitis. Also, side effects (epigastric pain, mild diarrhea, mild itching, and mild rash) were monitored after the medications. Moreover, on the third day of treatment, based on the response to treatment, we decided whether to continue the current antibiotic treatment or change it.

\section{Statistical Analysis}

The results were expressed as mean and standard deviation for quantitative variables and percentage for qualitative variables. The independent samples t-test was performed to compare the quantitative variables. The qualitative variables were also compared by the chi-square test or Fisher's exact test. We analyzed the data using IBM Statistical Package for the Social Sciences Statistics for Windows, version 23 (IBM Corp., Armonk, N.Y., USA) at a significance level of 0.05 or less.

\section{Ethical Considerations}

Written informed consent was obtained from patients who were given sufficient information about the study before the intervention. The patients were assured of the confidentiality of their information and access to the research results if they wished.

This study was approved by the Ethics Committee of Shahid Beheshti University of Medical Sciences in Tehran, Iran (approval ID: IR.SBMU.RETECH.REC.1398.86, date: 07.05.2019).

\section{Results}

In this study, 33 patients were assigned to the control group (A) and 31 patients were assigned to the intervention group (B). Table 1 shows the baseline characteristics of patients. The mean age of patients was $50.52 \pm 2.10$ years and $51.56 \%$ of the patients were male. There were no significant differences between the two groups in terms of age $(p=0.889)$ and gender $(p=0.780)$. Also, there were no significant differences between the two groups in terms of history of diabetes mellitus ( $p=0.666)$, antibiotic use $(p=0.594)$, trauma $(p=0.722)$, cellulitis $(p=0.529)$, and smoking $(p=0.705)$. In addition, none of the patients in the two groups had venous insufficiency, lymphatic drainage disorder, and preexisting skin infections.

Table 1. Comparison of baseline characteristics of patients in the two groups

\begin{tabular}{|c|c|c|c|c|}
\hline \multirow{2}{*}{\multicolumn{2}{|c|}{$\begin{array}{l}\text { Characteristics } \\
\text { Control (cefazolin alone) }\end{array}$}} & \multicolumn{2}{|l|}{ Groups } & \multirow[t]{2}{*}{$p$ value } \\
\hline & & \multicolumn{2}{|c|}{$\begin{array}{l}\text { Intervention } \\
\text { (cefazolin+naproxen) }\end{array}$} & \\
\hline \multirow[t]{2}{*}{ Gender } & Male & $18(60.0)$ & $15(44.1)$ & \multirow[t]{2}{*}{0.780} \\
\hline & Female & $15(40.0)$ & $16(55.9)$ & \\
\hline \multicolumn{2}{|l|}{ Age } & $51.4 \pm 2.2$ & $49.6 \pm 2.1$ & 0.889 \\
\hline \multicolumn{2}{|c|}{ History of diabetes mellitus } & $7(21.2)$ & $5(16.1)$ & 0.666 \\
\hline \multicolumn{2}{|c|}{ History of antibiotic use } & $10(30.3)$ & $7(22.6)$ & 0.594 \\
\hline \multicolumn{2}{|c|}{ History of trauma } & $6(18.2)$ & $7(22.6)$ & 0.722 \\
\hline \multicolumn{2}{|c|}{ Previous cellulitis } & $5(15.2)$ & $7(22.6)$ & 0.529 \\
\hline \multicolumn{2}{|c|}{ History of smoking } & $8(24.2)$ & $6(19.4)$ & 0.705 \\
\hline
\end{tabular}

Values are expressed as no. (\%) or mean \pm SD unless otherwise indicated.

SD: Standard deviation 
Table 2 shows the outcome of the medication in the two groups. The body temperature of the patients in two groups was on the first, third, fifth day of the study. The mean body temperatures of the two groups were not different on the first $(p=0.762)$, third $(p=0.789)$, and fifth day $(p=0.893)$. Figure 1 shows the trend of the patients' body temperature changes over time. The improvement of clinical symptoms on the third day was significantly $(p=0.045)$ more in group B $(90.3 \%)$ than in group A (51.5\%). Also, the clinical improvement on the fifth day was significantly $(p=0.036)$ higher in group $B(100 \%)$ than in group A (69.7\%). Figure 2 shows the improvement of clinical symptoms over time.

The mean hospitalization periods in the control $(5.62 \pm 1.00)$ and intervention $(4.04 \pm 1.00)$ groups were significantly different $(p=0.012)$. Figure 3 shows the prevalence of side effects in the

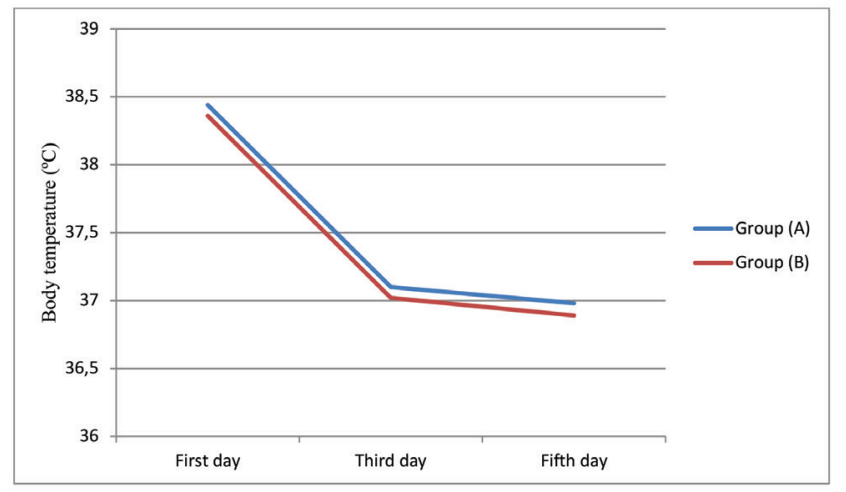

Figure 1 . Trend of body temperature changes in the control (A) and intervention (B) groups two groups. There was no significant difference between the two groups in terms of side effects.

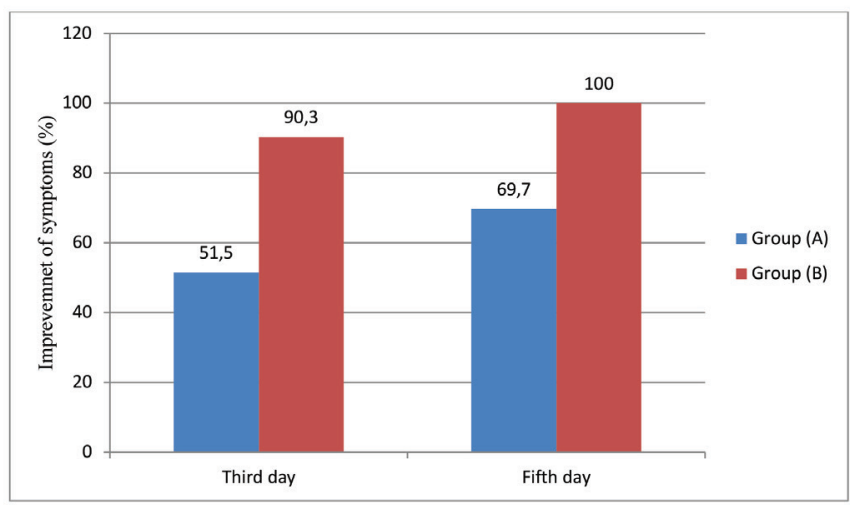

Figure 2. The improvement of clinical symptoms over the time in the control $(A)$ and intervention (B) groups

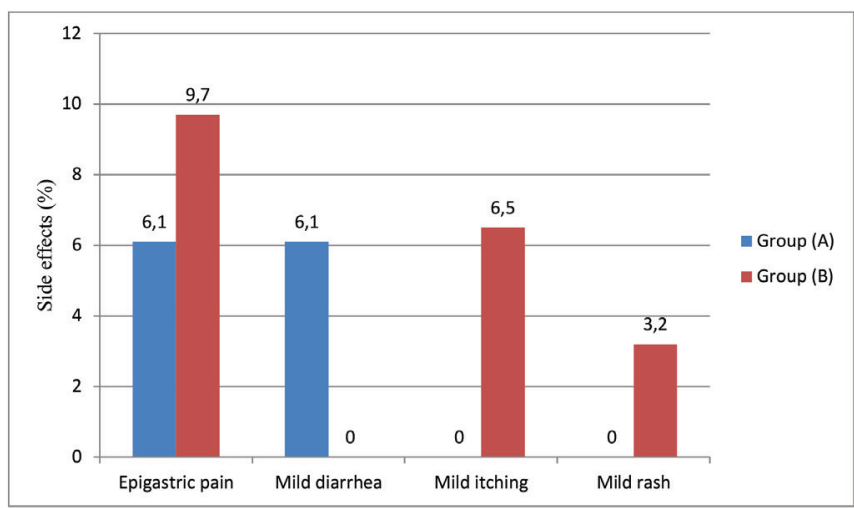

Figure 3. The prevalence of post-treatment side effects in the control (A) and intervention (B) groups

Table 2. Comparison of the outcomes of the medication in the two groups

\begin{tabular}{llll}
\hline Characteristics & Groups & & p value \\
\cline { 2 - 3 } & Control (cefazolin alone) & $\begin{array}{l}\text { Intervention } \\
\text { (cefazolin+naproxen) }\end{array}$ & \\
\hline Body temperature & & $38.36 \pm 0.22$ & 0.762 \\
\hline First day & $38.44 \pm 0.26$ & $37.02 \pm 0.10$ & 0.789 \\
\hline Third day & $37.10 \pm 0.12$ & $36.89 \pm 0.07$ & 0.893 \\
\hline Fifth day & $36.98 \pm 0.09$ & & 0.045 \\
\hline Improvement of clinical symptoms & & $28(90.3)$ & 0.036 \\
\hline Third day & $17(51.5)$ & $31(100)$ & 0.012 \\
\hline Fifth day & $23(69.7)$ & $4.04 \pm 1.00$ & \\
\hline Hospitalization period & $5.62 \pm 1.00$ & & 0.673 \\
\hline Side effects after treatment & & $3(9.7)$ & 0.494 \\
\hline Epigastric pain & $2(6.1)$ & $0(0.0)$ & 0.494 \\
\hline Mild diarrhea & $2(6.1)$ & $1(3.2)$ & 0.698 \\
\hline Mild itching & $0(0.0)$ & & \\
\hline Mild rash & $0(0.0)$ & & \\
\hline
\end{tabular}

Values are expressed as no. (\%) or mean \pm SD unless otherwise indicated.

SD: Standard deviation 
Besides, none of the patients had complications, such as abscess, sepsis, or death. All patients recovered completely by the seventh day of hospitalization and none received oral medication after discharge.

\section{Discussion}

It is necessary to carefully monitor the clinical course of patients with cellulitis. If not treated properly, there is a possibility of its extension to other skin surfaces, recurrent infection, risk of systemic spreading, and incidence of worse complications, such as sepsis and severe abscesses ${ }^{[18]}$. In this regard, due to the high diversity of cellulitis-causing bacterial strains, broad-spectrum therapies with the dual goals of suppressing bacterial strains and inhibiting inflammatory responses induced by cytokines are recommended. Accordingly, special attention has been paid to the MRSA strains, which can have far more adverse consequences following the development of cellulitis. A variety of antibiotic regimens with or without anti-inflammatory drugs have been used in the treatment of cellulitis. However, so far, no selective and standard line of treatment has been provided to treat this condition ${ }^{[16,19]}$. Since non-purulent cellulitis is not mainly caused by Streptococcus, there is no need for the initial treatment to cover the MRSA strains. Most purulent cellulitis is caused by MRSA strains, which require appropriate antibiotics. Also, in patients with abscesses, incision and drainage are the main treatment modalities ${ }^{[20]}$.

The present study aimed to compare the efficacy and outcome of two treatment regimens, including administration of cefazolin alone and cefazolin combined with naproxen as an NSAID. Based on our results, the body temperature of both groups within five days of treatment with both medications was completely normal. However, the combination therapy in our interventional study was superior to the monotherapy because, first, the improvement in clinical manifestations in the combination therapy was far more pronounced than in the monotherapy (cefazolin alone). Second, the combination therapy reduced the duration of hospitalization. Reducing the duration of hospitalization itself effectively decreases the risk of other opportunistic nosocomial infections and the likelihood of spreading cellulitis and other morbidities. Due to the safety of this combination therapy, in patients diagnosed with cellulitis, combination therapy with naproxen can be used as the first-line of treatment with high confidence.

Various studies have employed various regimens to treat cellulitis, although a study similar to ours was not found in the literature. The study by Zarezade et al. ${ }^{[21]}$ reported a much higher efficacy of cefazolin compared to ceftriaxone in the treatment of cellulitis. Davis et al. ${ }^{[16]}$ documented that coadministration of cephazolin with acetaminophen improved the condition of patients with cellulitis, with approximately $73 \%$ of the patients responding well to the treatment. Therefore, in the abovementioned studies, the effect of cefazolin as an effective antibiotic in the treatment of cellulitis can be far more favorable than different types of cephalosporins.

There are also several studies on the efficacy of various NSAIDs in the treatment of cellulitis, the efficacy of which has been confirmed particularly in the improvement of inflammatory and systemic symptoms of the disease. Ko et al. ${ }^{[15]}$ indicated that naproxen use in patients with cellulitis is more efficacious than the antibiotic cephalexin. Zervos et al. ${ }^{[14]}$ found that naproxen showed appropriate efficacy (85\%), while the antibiotic alone showed relative efficacy (43\%) in the treatment of cellulitis. Dall et al. ${ }^{[17]}$ found that the addition of NSAIDs effectively accelerates recovery and that cellulitis-induced inflammation was relieved in $9.1 \%$ and $82.8 \%$ of the patients, respectively. In addition, perfect treatment of cellulitis took four days and more than eight days, respectively. Interestingly, the treatment with naproxen alone sometimes has even more acceptable therapeutic effects than some antibiotics. Based on our findings, the combination therapy of cefazolin with naproxen has high efficacy to cure cellulitis, even in short term. However, due to the small sample size of our study, it is essential to conduct more comprehensive studies with larger sample sizes.

Our study had some limitations. This study was an open-label study without blinding and placebo. To remove the placebo effect, it is necessary to design a blinded controlled study. We followed up with the patients for seven days. If we followed up with the patients for a longer period, we could have had a more complete judgment of the effect of the intervention, recurrence, and rehospitalization.

\section{Conclusion}

In cases of cellulitis, combination therapy with cefazolin and naproxen is far more effective than monotherapy with cefazolin. The administration of the first regimen was associated with further improvement of clinical manifestations and a shorter duration of hospitalization.

\section{Ethics}

Ethics Committee Approval: This study was approved by the Ethics Committee of Shahid Beheshti University of Medical Sciences in Tehran, Iran (approval ID: IR.SBMU.RETECH. REC.1398.86, date: 07.05.2019).

Informed Consent: Consent form was filled out by all participants.

Peer-review: Externally and internally peer-reviewed. 


\section{Authorship Contributions}

Surgical and Medical Practices: S.T., B.H., S.S., Concept: B.H., Design: S.T., Data Collection or Processing: S.T., S.S., A.K., Analysis or Interpretation: S.S., A.K., Literature Search: S.T., Writing: S.T.

Conflict of Interest: No conflict of interest was declared by the authors.

Financial Disclosure: Funding for this research was provided by the Infectious Diseases and Tropical Medicine Research Center, Shahid Beheshti University of Medical Sciences, Tehran, Iran.

\section{References}

1. Hsu RJ, Chou CC, Liu JM, Pang ST, Lin CY, Chuang HC, Chuang CK, Wang HW, Chang YH, Lin PH. The association of cellulitis incidence and meteorological factors in Taiwan. Epidemiol Infect. 2019;147:e138.

2. Burian EA, Karlsmark T, Franks PJ, Keeley V, Quéré I, Moffatt CJ. Cellulitis in chronic oedema of the lower leg: an international cross-sectional study. $\mathrm{Br}$ J Dermatol. 2021;185:110-8.

3. Bisno AL, Stevens DL. Streptococcal infections of skin and soft tissues. $\mathrm{N}$ Engl J Med. 1996;334:240-5.

4. Sullivan T, de Barra E. Diagnosis and management of cellulitis. Clin Med (Lond). 2018;18:160-3.

5. Tianyi $\mathrm{FL}$, Mbanga CM, Danwang C, Agbor VN. Risk factors and complications of lower limb cellulitis in Africa: a systematic review. BMJ Open. 2018;8:e021175.

6. Dupuy A, Benchikhi H, Roujeau JC, Bernard P, Vaillant L, Chosidow O, Sassolas B, Guillaume JC, Grob JJ, Bastuji-Garin S. Risk factors for erysipelas of the leg (cellulitis): case-control study. BMJ. 1999;318:1591-4.

7. Sapuła M, Krankowska D, Wiercińska-Drapało A. In Search of Risk Factors for Recurrent Erysipelas and Cellulitis of the Lower Limb: A CrossSectional Study of Epidemiological Characteristics of Patients Hospitalized due to Skin and Soft-Tissue Infections. Interdiscip Perspect Infect Dis. 2020;2020:1307232.

8. Jeng $A$, Beheshti $M$, Li J, Nathan R. The role of $\beta$-hemolytic streptococci in causing diffuse, nonculturable cellulitis: a prospective investigation. Medicine (Baltimore). 2010;89:217-26.

9. Njim T, Aminde LN, Agbor VN, Toukam LD, Kashaf SS, Ohuma EO. Risk factors of lower limb cellulitis in a level-two healthcare facility in Cameroon: a case-control study. BMC Infect Dis. 2017;17:418.
10. Hannula-Jouppi K, Massinen S, Siljander T, Mäkelä S, Kivinen K, Leinonen R, Jiao H, Aitos P, Karppelin M, Vuopio J, Syrjänen J, Kere J. Genetic susceptibility to non-necrotizing erysipelas/cellulitis. PLoS One. 2013;8:e56225.

11. Pallin DJ, Binder WD, Allen MB, Lederman M, Parmar S, Filbin MR, Hooper DC, Camargo CA Jr. Clinical trial: comparative effectiveness of cephalexin plus trimethoprim-sulfamethoxazole versus cephalexin alone for treatment of uncomplicated cellulitis: a randomized controlled trial. Clin Infect Dis. 2013;56:1754-62.

12. Stevens DL, Bisno AL, Chambers HF, Dellinger EP, Goldstein EJ, Gorbach SL, Hirschmann JV, Kaplan SL, Montoya JG, Wade JC; Infectious Diseases Society of Americ. Practice guidelines for the diagnosis and management of skin and soft tissue infections: 2014 update by the Infectious Diseases Society of America. Clin Infect Dis. 2014;59:10-52.

13. Vary JC, O'Connor KM. Common dermatologic conditions. Med Clin North Am. 2014;98:445-85.

14. Zervos MJ, Freeman K, Vo L, Haque N, Pokharna H, Raut M, Kim M. Epidemiology and outcomes of complicated skin and soft tissue infections in hospitalized patients. J Clin Microbiol. 2012;50:238-45.

15. Ko K, Lee WK, Oh CY, Lee SH, Cho ST, Bang WJ, Shin TY, Choo MS, Cho JS, Lee YG, Yang DY. Is A Combination of Antibiotics and Non-Steroidal Anti-Inflammatory Drugs More Beneficial Than Antibiotic Monotherapy For The Treatment of Female Acute Uncomplicated Cystitis? A Randomized Controlled Pilot Study. Urol J. 2018;15:365-9.

16. Davis JS, Mackrow C, Binks P, Fletcher W, Dettwiller P, Marshall C, Day J, Pratt W, Tong SY. A double-blind randomized controlled trial of ibuprofen compared to placebo for uncomplicated cellulitis of the upper or lower limb. Clin Microbiol Infect. Clin Microbiol Infect. 2017;23:242-6.

17. Dall $L$, Peterson $S$, Simmons T, Dall A. Rapid resolution of cellulitis in patients managed with combination antibiotic and anti-inflammatory therapy. Cutis. 2005;75:177-80.

18. Blumberg G, Long B, Koyfman A. Clinical mimics: an emergency medicinefocused review of cellulitis mimics. J Emerg Med. 2017;53:475-84.

19. Cranendonk DR, Lavrijsen APM, Prins JM, Wiersinga WJ. Cellulitis: current insights into pathophysiology and clinical management. Neth J Med. 2017;75:366-78.

20. Breyre A, Frazee BW. Skin and Soft Tissue Infections in the Emergency Department. Emerg Med Clin North Am. 2018;36:723-50.

21. Zarezade M, Shaterzade F, Abedini S, Raadabadi M. Evaluating pattern of prescribing antibiotics in surgical wards of shahid rahnemon hospital compared to standard methods in 2015. JSSU. 2015;23:679-90. 